DOI: $10.20472 / T E .2016 .4 .4 .004$

\title{
THE STUDY OF UNIVERSITY STUDENTS' MOTIVATION
}

\author{
JANA M. SAFRANKOVÁ, MARTIN SIKYR
}

\section{Abstract:}

The goal of the paper is to define and discuss the problem of increasing quantity of university students and graduates and the impact of the university students' motivation on their attitudes to learning and studying at university. The paper is based on the analysis of available scientific literature and the comparison of the results of the authors' survey conducted among students of the Czech Technical university in Prague in the first decade of the twenty-first century and the authors' survey conducted among students of the College of Regional Development in Prague, the Masaryk Institute of Advanced Studies of the Czech Technical University in Prague and the School Management Centre of the Faculty of Education of Charles University in Prague in 2016. The new data were obtained from 415 students. The results show some interesting tendencies in students' attitudes to learning and studying at university in the Czech Republic.

\section{Keywords:}

university student, higher education, human capital, Czech Republic

JEL Classification: $129, \mathrm{~A} 14,121$

\section{Authors:}

JANA M. SAFRANKOVÁ, The College of Regional Development, Czech Republic, Email: jana.safrankova@vsrr.cz MARTIN SIKYR, Czech Technical University in Prague, Masaryk Institute of Advanced Studies, Czech Republic, Email: martin.sikyr@cvut.cz

\section{Citation:}

JANA M. SAFRANKOVÁ, MARTIN SIKYR (2016). The study of university students' motivation. International Journal of Teaching and Education, Vol. IV(4), pp. 48-59., 10.20472/TE.2016.4.4.004 


\section{Introduction}

Universities represent an important part of the educational system. Higher education is currently undergoing significant changes. The approach to education and the value of education are changing. It can be stated that the education has increasingly different value than it had in the previous fifty years or more. Universities and their graduates are an important part of the education in a knowledge society. They allow students to obtain and develop various knowledges, skills and abilities. Fourth industrial revolution and so called creative economy bring significant changes in educational system, mainly to university education followed by situation on the labour market. The same situation as in many European countries is at the Czech Republic. The goal of the paper is to describe and discuss the problem of increasing quantity of university students and graduates and their motivation to study university. The paper analyses the new situation in university education, some changes in the value of education in the present, since education today takes on a different character and different values for the generation coming into the labour market. Our research confirmed students of managerial-economic study programs.

In the Czech Republic there are many different public and private universities that provide different programmes for specialists (bachelors, engineers, doctors) of various economic, humanities, social and technical professions. In the last 20 years the quantity of university students and graduates raises and we asked what changes are in their motivation to study. Well educated and motivated young people determine the future prosperity and competitiveness of the society (Sekuloska, 2014). But university students must be motivated to learn and study at university to acquire and develop necessary technical and personal competencies (Wach et al., 2016).The authors' research results and teaching experience show that the motivation of students to learn and study at university is determined by the personal interest and too by quality of teaching (Kucharčíková, 2013; Marčíková, 2015).

The issue of education occupies a very important place in contemporary advanced societies that are sometimes referred to as learning or knowledge societies. The human capital includes various forms of investment into people. According to Becker (1993), education is "an investment that will in the future bring the individual revenue in the form of increased earnings as a reward for greater knowledge and skills, and therefore higher labour productivity and technological progress as a contribution to society". Becker divided human capital on specific, usable only in the company, and general human capital that can be used in more types of jobs. This division later became the basis for considering the need for employee motivation and corporate investments in the form of business education in both these two types of human capital. Blundell, Dearden, Meghir and Sianesi (1999) distinguish three components of human capital: universal, specific technical and scientific knowledge that is specific to the production or development of 
new technologies. The increasing importance of education is related to the increasing importance of science and its application in all basic areas of human life, to processes of democratization, to the increasing role of human being and to processes of individualization (Bartoš, 2015).

The first part of the paper presents a detailed description of the research methodology, scientific methods, collected data and definition of the alternative working hypotheses. The second part of the paper introduces the characteristics of changes in number of university students in the Czech Republic. The third part of the paper presents the results of the secondary analyses and of the researches along with the brief discussion. The new is that there are some aspects of the study motivation in last twenty years from point of view of Czech Republic. The final part - conclusion - presents the summary of the essential results of our research.

\section{Goal and method}

The aim of the paper is focused on some questions concentrated on the students' motivation in university education in context of changes in Czech society. The goal of the paper is to define and discuss the problem of increasing quantity of university students and graduates and the impact of the university students' motivation on their attitudes to learning and studying at university. The paper is based on the analysis of available scientific literature and the comparison of the results of the authors' questionnaire survey conducted among students of the Czech Technical university in Prague in the first decade of the twenty-first century and the authors' questionnaire survey conducted among students of the College of Regional Development in Prague, the Masaryk Institute of Advanced Studies of the Czech Technical University in Prague and the School Management Centre of the Faculty of Education of Charles University in Prague in 2016. The questionnaires were distributed to students personally and by e-mails.

This paper presents only selected results of the sociological empirical studies on opinions of university students in the year 2016 and retrospective in years 2001, 2004, 2011. Our research used the tools of descriptive statistics, including percentage and averages, pivot tables, the methods of comparison and deduction, Pearson's chi-square statistics at $5 \%$ significance level for the verification of existence of the statistically significant differences in the individual responses. The calculation was made in statistical software SPSS and some part were made in MS Excel. Data from CTU (2001 - 1755 students, 2004 - 2324 students, 2011 - 844 students) was analysed by Jana Šafránková and data from 2016 by both authors. 
The respondents in 2016 were students of the College of Regional Development in Prague (Urban and Regional Development Management and Security and Safety Management in Regions), the Masaryk Institute of Advanced Studies of the Czech Technical University in Prague (Personnel Management in Industrial Enterprises and Management and Economy of an Industrial Enterprise) and the Education Management Centre of the Faculty of Education of the Charles University in Prague (Education Management).

The questionnaire in 2016 included twenty two multiple choice questions focused on factors of students' motivation to study at university and their expectations about future career. The questionnaire was distributed to bachelor's and master's students. The relevant data were obtained from 415 students. The respondents were characterized by gender (28\% male, $72 \%$ female), age (6\% less than 20 years, $68 \% 20-24$ years, $6 \% 25$ 29 years, $4 \% 30-34$ years, $13 \% 35-49$ years, $3 \%$ more than 50 years), years of work experience $(43 \%$ less than 1 year, $21 \% 1-2$ years, $12 \% 3-5$ years, $7 \% 6-10$ years, $5 \% 11$ 15 years, 3\% 16-19 years, $9 \%$ more than 20 years), form of study (72\% full-time, $28 \%$ combined), and year of study ( $45 \%$ first year, $28 \%$ second year, $17 \%$ third year, $10 \%$ fifth year). Sampling errors was $3.0 \%$.

In summarising the positive and negative methodological experience at CTU we have any difficulties in the implementation of the initial research concept in the beginning of longitudinal research in the early 90 .years, but because the research had the opportunity to build on a survey of students starting in the 70s of the 20th century in the Czech Republic and at CTU, a significant methodological problems were absent. Newly was created some questions on changes of educational system, such as evaluation language teaching, study abroad, etc. With new surveys at The College of regional development, we are using as model the questionnaire for students and we start to testing differences between students and graduates of technical background and management of regional development.

The paper contains too results of the social empirical studies and the secondary analysis of statistical data of the Czech Statistical Office, the Ministry of Education, Youth and Sports of the Czech Republic (data on numbers of university graduates), OECD and Eurostat realised by authors of the papers - Jana M. Šafránková and Martin Šikýr.

For this paper we set two alternative working assumptions:

- A1: There are new situation in university education, increasing the number of students and graduates

- A2: The value of education in the present is changing from knowledge to university title. 


\section{$3 \quad$ Results and discussion}

\subsection{Number of university students}

Radical changes in society have a significant impact on education, on its overall character as well as on its individual parts, especially on participants in the educational process. After 1989, the period of social and economic transformation brought great diversification into the system of education as well as into the system of production (Machonin, Tuček et al., 1996; Matějů and Večerník, 2015). There has been a rapid development of tertiary sphere (services) and quaternary sphere (education and science). Many young people have had the opportunity to study at university and many new private universities have been founded, but they are focused exclusively on desired economic, managerial and social discipline. There has been founded no technical private university.

The number of students in higher education, i.e. universities and colleges is rapidly grown in the period of fifteen years from 2000 to 2014. In 2001, in Czech higher institutions, there were studied 203,500 students and in year 2010 396,000 students. This increase most likely because at that period studied numerically relatively large groups born between 1980 and 1994. After 2010 the number of students is slowly decreases because the students are from numerically weaker age groups born after 1995, and this trend will continue. It is estimated that the number of students could drop after 2020 to 270,000 . The social changes and changes in lifestyle resulted in a significant increase of the number of female students from 98,000 in 2000 to more than 205,000 in 2013.

Table 1. Number of university students and graduates in the Czech Republic 2001-2015

\begin{tabular}{ccc}
\hline Year & Students in thousands & Graduates in thousands \\
\hline 2001 & 203,5 & 30,1 \\
\hline 2005 & 289,5 & 44,3 \\
\hline 2010 & 396,0 & 88,1 \\
\hline 2011 & 392,1 & 93,0 \\
\hline 2012 & 381,0 & 93,9 \\
\hline 2013 & 367,9 & 91,6 \\
\hline 2014 & 347,3 & 88,1 \\
\hline 2015 & 326,9 & 82,1 \\
\hline
\end{tabular}

Source: data of the Czech Statistical Office and the Ministry of Education, Youth and Sports of the Czech Republic, own calculation

Public universities themselves made no strong move towards the two-tier (binary) system of tertiary education. "Although the number of students rose by almost $60 \%$ between 1989 and 2001, the offer of educational opportunities was too low to meet the steeply 
rising demand the offer of educational opportunities was too low to meet the steeply rising demand for tertiary education. The chance of being admitted did not change; it remained at about $50 \%$, and it started to grow only after 2001, mostly owing to the combined effect of a drop in the size of the relevant age cohort and the growing proportion of students admitted to short bachelor's programmes. Given the rapid growth in the number of secondary school graduates and the steady accumulation of unsatisfied demand, the transition from secondary to tertiary education is still the most critical moment in an educational career" (Matějů and Večerník, 2003, p. 409).

\subsection{Students motivation to study university}

An important part of the characteristics of the current students are themes incentive structure of their studies. In accordance with the already stated an interest in higher education is the most important motive study argues opportunity to improve their education, skills and abilities (such motive considered as very important or important nine-tenths of the current students - university education represents not only a theme and a very important value not only as a means but also a goal in life. in addition to this motive has a very important meaning, or at least for such proclaimed, achieving a good career and financial rewards. These three themes "act" clearly to the fore, motives and values. They represent the possibility of obtaining a university degree, deepening interest in the particular discipline and good social status. Significantly smaller role in representing such moments as the opportunity to lead a student's life, but for more than two fifths of students among the motive to important factors incentive effects. The motivational factors may contribute to create a favorable climate and expectations of successful learning, but also put high demands on their performance. Those motives represent how certain needs and objectives, which in varying degrees affect student behavior. Especially the aforementioned three most important themes can create, respectively. Creating favorable conditions for university studies (interest in the study, interest in the field) and also put a strain on teaching (in preparation for a future career), but also in shaping the social conditions (pay). Those motives in studies are long-term and at any given time are applied in the past. Conditions for their realization, however, were different. E.g. according to research by university students for technical decisive motives in studies represented the opportunity to exercise creative and interesting work and knowledge in the field. Regarding the motif postponement entry into practice, then this factor attributed a high value of more than half the students.

One of the very important conditions for successful and beneficial graduation is definitely the intensive motivation of students to study at university, learn and adopt necessary professional knowledge, skills and abilities. According to the authors' surveys results, we used for example of changing students' motivation to study, existing data. Although we are aware that data are not exactly comparative, they show tendencies of changes in the 
value of higher education. From the surveys indicated a shift in values associated with the study, it is possible to show, that in years 2001-2011 "The opportunity to develop my education, skills and abilities" $89-84 \%$ of students stated that they are motivated to study at university by an effort to developed their knowledge. Other factors are increasing - their chances on the labour market, in year 2001 there was $42 \%$ and in year $201186 \%$ of students, $50-75 \%$ of students declare that they were study for graduation of university for university title. The statement to study for professional development is increases too. It is interesting finding that in all three included surveys is the same percentage ratings in enjoyment of student life (see Table 2).

Table 2. Motives of students to study university

\begin{tabular}{lccc}
\hline Motives & Students 2001 in \% & Students 2004 in \% & Students 2011 in \% \\
\hline $\begin{array}{l}\text { The opportunity to } \\
\text { develop my skills, } \\
\text { knowledge, abilities }\end{array}$ & 89 & 89 & 84 \\
\hline $\begin{array}{l}\text { Better chances on } \\
\text { the labour market }\end{array}$ & 42 & 61 & 86 \\
\hline $\begin{array}{l}\text { Graduation from } \\
\text { university }\end{array}$ & 50 & 73 & 75 \\
\hline Higher earnings & 69 & 88 & 81 \\
\hline $\begin{array}{l}\text { Professional } \\
\text { development }\end{array}$ & 43 & 42 & 60 \\
\hline Career prospects & 78 & 88 & - \\
\hline $\begin{array}{l}\text { Enjoyment of student } \\
\text { life }\end{array}$ & 31 & 42 & 31 \\
\hline
\end{tabular}

Source: Safrankova, 2001, 2004, 2011

Table 3. Motives of students to study university (2016)

\begin{tabular}{lccc}
\hline Motives & $\begin{array}{c}\text { Full time } \\
\text { students in \% }\end{array}$ & $\begin{array}{c}\text { Part time } \\
\text { students in \% }\end{array}$ & Total in \% \\
\hline Need of university education & 36 & 20 & 31 \\
\hline Graduation from university & 66 & 46 & 60 \\
\hline Professional development & 51 & 30 & 51 \\
\hline Better chances on the labour market & 88 & 22 & 69 \\
\hline Higher earnings & 68 & 7 & 51 \\
\hline Career prospects & 23 & 10 & 21 \\
\hline Enjoyment of student life & 0 & 3 & 3 \\
\hline
\end{tabular}

Source: authors

From the surveys indicated a shift in values associated with the study, it is possible to show, that in year 2016. There are large differences between full time and part time 
students' opinions. "The opportunity to develop my education, skills and abilities" was not indicated. New factor is "Need of university education" $31 \%$ with disparity between full time $-36 \%$ and part time $-20 \%$ of respondents. The factor "chances on the labour market", in year 2001 there was $42 \%$ and in year $201186 \%$ and $201688 \%$ but part time students indicated only $22 \%$. In last decade $50-75 \%$ of students declare that they were study for graduation of university - for university title, now there $60 \%$ in total. The statement to study for professional development also increases; in 2016 is the same as in 2011. It is interesting finding that in all three included surveys is the same percentage ratings in enjoyment of student life (see Table 3 ).

Whereas it shows that the analysis of data from previous research and over 20 years old, can be statistically demonstrated changes in the value approaches to the study, for the future steps in research it will be useful to compare more data about student motivation to study at universities.

\subsection{Satisfaction with studies on contemporary university}

One of the fundamental characteristics of students and university graduates is their attitude to education. It is the future of a highly challenging (in many ways) specialized profession or occupation imposed on them and will put high demands, not only in terms of the field. Students have a higher degree of identification with higher education; it is confirmed by subjective (verbally expressed an attitude) that, if called, re-election, i.e. the possibility again to decide whether to attend university, such a choice would be reiterated, they confirmed. Such an attitude intrigued and occupies percentage of students with small variations in certain years. It is however necessary to supplement (in the interest of objectivity of information) that this statement applies to students who continue their studies. Confirmation of identification with university students study demonstrated effectively, i.e. Mentioned characteristics can be considered as very important for the period of undergraduate study, and further development and not just students. According to the results of sociological surveys of students in our society there are some basic characteristics. (Šafránková and Franěk, 2008)

Important feature is the students' identification with their focus, i.e. a field of study. In this case such identification is confirmed $60-70 \%$ of students; therefore it is a "confirmation" of interest in the field of study. Identification with the university, "says" about $80 \%$ of the students. This means that the study in greater or lesser extent consistent with their intentions. That does not mean that fully identify with the studied study program. While some of the students expressed the same professional focus, but would be realized at another university. The proportion of such students is around $10 \%$. It cannot ignore the other part of the students who identify with a university degree, but a different focus; the proportion of students in the last 20 years, ranging between $8-15 \%$. Further, the last part 
is the students who voted at the possibility of re-election, a different type of education or vocational college courses or direct transition into practice. Their share oscillates between $2-4 \%$.

Table 4. Interest reselection same university $(2001,2004,2011)$

\begin{tabular}{lccc}
\hline Interest of study & 2001 in $\%$ & 2004 in \% & 2011 in \% \\
\hline Same university, same program & 67 & 66 & 63 \\
\hline Same university, other program & 17 & 15 & 20 \\
\hline Other university & 14 & 18 & 15 \\
\hline Not to study university & 2 & 1 & 2 \\
\hline
\end{tabular}

Source: authors

Table 5. Interest reselection same university (2016)

\begin{tabular}{lccc}
\hline Interest of study & $\begin{array}{c}\text { Full time } \\
\text { students in \% }\end{array}$ & $\begin{array}{c}\text { Part time } \\
\text { students in \% }\end{array}$ & Total in \% \\
\hline Same university, same program & 61 & 90 & 68 \\
\hline Same university, other program & 4 & 10 & 3 \\
\hline Other university & 31 & & 26 \\
\hline Not to study university & 4 & & 3 \\
\hline
\end{tabular}

Source: authors

The relationship to the field also suggests, among other things with the choice of a particular university. An essential feature of students is the fact that studied university is among them in the first place. According to research from the first decade of the $21 \mathrm{st}$ century, more than $80 \%$ of studying at school, they clearly preferred.

Table 6. Actual interest of study program at university $(2004,2011)$

\begin{tabular}{lcc}
\hline Interest of study program & 2004 in \% & 2011 in \% \\
\hline $\begin{array}{l}\text { I am very interested and program corresponds to in my } \\
\text { expectations }\end{array}$ & 35 & 29 \\
\hline $\begin{array}{l}\text { I am interested and program not fully corresponds to in } \\
\text { my expectations }\end{array}$ & 51 & 57 \\
\hline $\begin{array}{l}\text { I am partly interested but does not match my } \\
\text { expectations }\end{array}$ & 9 & 10 \\
\hline I am slightly interested, but I finish studies & 5 & 4 \\
\hline
\end{tabular}

Source: authors 
Table 7. Actual interest of study program at university (2016)

\begin{tabular}{lccc}
\hline Interest of study program & $\begin{array}{c}\text { Full time } \\
\text { students in \% }\end{array}$ & $\begin{array}{c}\text { Part time } \\
\text { students in \% }\end{array}$ & Total in \% \\
\hline $\begin{array}{l}\text { I am very interested and program } \\
\text { corresponds to in my expectations }\end{array}$ & 20 & 42 & 25 \\
\hline $\begin{array}{l}\text { I am interested and program not fully } \\
\text { corresponds to in my expectations }\end{array}$ & 55 & 1 & 54 \\
\hline $\begin{array}{l}\text { I am partly interested but does not } \\
\text { match my expectations }\end{array}$ & 20 & 0 & 5 \\
\hline $\begin{array}{l}\text { I am slightly interested, but I finish } \\
\text { studies }\end{array}$ & 5 & 57 \\
\hline
\end{tabular}

Source: authors

Differences between students of the university are not particularly large (ranging between $77-91 \%$ ). For smaller portion, about 15\% accounted for studies at the university some workarounds. By selecting the "emergency" it was only for a minor part (2 -5\%). One university study and studied students who identify as a field of study, they constitute a large majority, but also students who link to the study program is weaker; They have slightly different ideas of how their specialization. Relationship to the chosen expresses their studies next character, i.e. Images and interested in learning. A large majority of students, more than $85 \%$, has studied a program or field of interest, but ideas about art are quite different. Just more than one-third of students studied field corresponds fully to their ideas, and more than half $(52 \%)$ have somewhat different ideas. Students express opinions in the data table 6 and 7.

\subsection{Education and students and graduates knowledge at labour market}

According to the results of sociological surveys of graduates from the Czech Technical University in Prague (Šafránková, 1996-2013) and students from The College of Regional Development (Šafránková and Šikýř, 2016) the most important skills necessary for successful employment are problem-solving skills, the ability to learn new knowledge, communication and teamwork skills. In terms of professional qualification, on the one hand, graduates appreciate general knowledge in the field of their interest. On the other hand, they feel the lack of relevant practical experience. According to the graduates, they had to improve mainly their knowledge of foreign languages.

The table 8 shows the opinions of university students on skills important for their success on the labour market. First row with $79 \%$ approval of respondents considered the most important ability to communicate with people. There disagree with the views of graduates from the previous survey, but rather closer view of employers who consider this competence is currently one of the most important. Second row with $76 \%$ approval to 
ability to solve problems coincides with the views of graduates and their employers. On the third rank is the ability to apply their knowledge and team work ability with $57 \%$ approval of respondents. The fifth rank the ability to acquire new knowledge, with $55 \%$ approval is close to results from graduates and theirs employers. Six rank is ability to adapt to business requirements and the last is risk capacity. In this case we can say that on the contrary this ability in reality will be among the most important.

Table 8. Important skills for the labour market by students opinions (possibility of multiple choice)

\begin{tabular}{lcc}
\hline Skill for the labour market & Students & Rank \\
\hline Ability to acquire new knowledge & $55 \%$ & 5. \\
\hline Ability to apply their knowledge & $57 \%$ & $3 .-4$. \\
\hline Ability to communicate with people & $79 \%$ & 1. \\
\hline Ability to adapt to business requirements & $40 \%$ & 6. \\
\hline Teamwork ability & $57 \%$ & $3 .-4$. \\
\hline Risk capacity & $36 \%$ & 7. \\
\hline Ability to solve problems & $76 \%$ & 2. \\
\hline
\end{tabular}

Source: authors

\section{Conclusion}

Universities prepare their students to their best possible use in practice. Their preparation is not dependent only on the quality of studies and teachers at universities and even not only on the quality of study programs. It also depends on the student interest in studying at university. For this reason, it is important to know the students' motivation to learn and study at different universities. Students are not only the object, but mostly currently the subject of the educational process. The paper summarizes the current results of the authors' research focused on students' motivation to learn and study at university in retrospective of twenty years. The authors' questionnaire survey in 2016 was focused on the challenges of employability of management students of the College of Regional Development in Prague, the Masaryk Institute of Advanced Studies of the Czech Technical University in Prague and the School Management Centre of the Faculty of Education of Charles University in Prague, we used only one part concentrated to motivation on study at university and important skills for labour market. The motivation of students to learn and study at university is definitely the important condition for successful and beneficial graduation. These students should have a good chance to succeed on the labour market due to the possibility to acquire broader knowledge, skills and abilities, but they should change their attitude to the preparation for the future career. General feedback and necessary information may provide some sociological methods and techniques. One important issue is to motivate students to learn and study. The results 
confirm main findings of earlier studies cited above and show some interesting tendencies in the students' motivation to learn and study at university that should be well analysed and discussed. These issues open up new possibilities for further research in the field of the employability of management students. The intention is to use the results of the authors' questionnaire survey and extend the survey to the partner universities.

\section{Acknowledgments}

The research leading to these results has received funding from the PROJECT titled "Opinions of graduates and students to apply acquired knowledge/competence to practice VSRR" in the frame of the program "Internal grants" under the Grant agreement number IGA_Z9_02_2015.

\section{References}

Bartoš, P., Rahman, A., Horák, J., Jáčová, H. (2015). Education and Entrepreneurship in the SME Segment in Economic Transformation. Economics \& Sociology, Vol. 8, No. 2, pp. 227-239. DOI: 10.14254/2071- 789X.2015/8-2/16

Becker, G. S. (1993). Human Capital: A Theoretical and Empirical Analysis, with Special Reference to Education. 3rd ed. Chicago: University of Chicago Press. https://doi.org/10.7208/chicago/9780226041223.001.0001

Blundell, R. Dearden, L., Meghir, C., Sianesi, B. (1999). Human Capital Investment: The Returns from Education and Training to the Individual, the Firm and the Economy [online]. Fiscal Studies, vol. 20, no. 1, pp. 1-23 [cit. March 25, 2016]. Available at: http://www.ifs.org.uk/fs/articles/0017a.pdf https://doi.org/10.1111/j.1475-5890.1999.tb00001.x

Kucharčíková, A. (2013). The quality improvement of the university education. Procedia - Social and Behavioral Sciences, pp. 2993-3001. https://doi.org/10.1016/j.sbspro.2013.12.345

Machonin, P., Tuček, M. et al. (1996). Česká společnost $v$ transformaci. Praha: SLON.

Maršíková, K. (2015). The Value of a University Degree in the European Context: the Case of Part-time Students in the Czech Republic. Economics and Sociology, Vol. 8, No. 3, pp. 260-271. DOI: 10.14254/2071-789X.2015/8-3/18

Matějů P., Večerník, J. (2003). Czech Higher Education at the Crossroads. Sociologický Časopis, Vol. 39, No. 3, pp.296-299.

Matějů, P., Večerník, J. (2015). Kompetence, vzdělání a lidský kapitál v České republice ve světle dat OECD-PIAAC. Politická ekonomie, Vol. 63, No.2, pp. 185-203. https://doi.org/10.18267/j.polek.996

Number of university students (2000 - 2015) Czech Statistical Office, https://www.czso.cz/csu/czso/home

Number of university students $(2000$ - 2015) Ministry of Education, Youth and Sports, http://dsia.uiv.cz/vystupy/vu_vs_f4.html

Sekuloska, J. D. (2014). Higher education and training as crucial pillars in creating the competitiveness of nation. Procedia - Social and Behavioral Sciences, pp. 241-246. https://doi.org/10.1016/j.sbspro.2014.11.182

Šafránková, J. (1996-2013). Positions of CTU graduates on the labour market. Sociological surveys, Praha: ČVUT.

Šafránková, J., Šikýr̆, M. (2016). Employability of Students from the College of Regional Development. Sociological survey, internal material, Praha: VŠRR.

Šafránková, J., Franěk, R. (2008). CTU students and graduates. Praha: ČVUT.

Tuček, M. (1995). Zpráva o vývoji sociální struktury společnosti: Česká republika 1945-1993. Praha: Foundation START. 